\title{
HASIL PENILAIAN DIRI DAN PENILAIAN TEMAN SEBAYA DIBANDINGKAN DENGAN ASSESSMENT DOSEN UNTUK HASIL PRODUK MATA KULIAH BODY OTOMOTIF
}

\author{
Rachman Arifin' ${ }^{1}$, Inu H. Kusumah ${ }^{2}$, Ibnu Mubarak ${ }^{3}$ \\ Universitas Pendidikan Indonesia \\ J1. Dr. Setiabudhi No. 229 Bandung 40154 \\ rachman.arifin.24@gmail.com
}

\begin{abstract}
ABSTRAK
Penelitian ini bertujuan untuk mengetahui hasil self assessment, peer assessment, dengan assessment dosen untuk hasil produk mata kuliah body otomotif. Penelitian inni menggunakan metode deskriptif dengan pendekatan kuantitatif dan desain penelitian cross sectional. Penelitian ini dilakukan pada mahasiswa konsentrasi otomotif DPTM FPTK UPI S1 angkatan 2013 yang berjumlah 54. Sampel penelitian adalah mahasiswa konsentrasi otomotif DPTM FPTK UPI S1 angkatan 2013 yang berjumlah 20 orang. Hasil penelitian pada penilaian diri (self assessment) untuk hasil produk mata kuliah body otomotif dengan keseluruhan nilai yang didapat adalah 76,25 pada katagori terampil. Penilaian teman sebaya (peer assessment) dengan keseluruhan nilai didapat 75 pada katagori terampil.Assessment dosen untuk hasil produk mata kuliah body otomotif berupa miniatur mobil yang dinilai oleh dosen mata kuliah adalah nilai didapat 84 pada katagori terampil. Perbandingan antara self assessment and peer assessment dengan assessment dosen masuk dalam katagori yang sama yaitu katagori terampil dengan nilai rata-rata self assessment dan peer assessment 76 dan assessment dosen 84. Penelitian ini disimpulkan terdapat kesamaan antara self assessment and peer assessment dengan assessment dosen untuk hasil produk mata kuliah body otomotif.
\end{abstract}

Kata kunci: penilaian diri, penilaian teman sebaya, assessment, body otomotif.

\section{PENDAHULUAN}

Peserta didik bisa dilibatkan pada saat evaluasi ataupun penilaian dengan menggunakan penilaian diri dan penilaian teman sebaya (self and peer assessment). Penilaian diri atau self assessment merupakan teknik penilaian sikap, pengetahuan, dan keterampilan yang dilakukan sendiri oleh peserta didik secara reflektif (Zulharman, 2007). Pendidik dapat menggunakan penilaian teman sebaya atau peer assessment untuk memperkuat penilaian autentik dan non-autentik.

Kegiatan praktikum merupakan bagian penting dari kegiatan belajar mengajar pada mata kuliah produktif. Melalui kegiatan praktikum dapat diketahui aspek keterampilan peserta didik dan seberapa baik peserta didik dalam menerapkan informasi yang diperoleh selama kegiatan pembelajaran (Putra, 2012). Oleh karena itu, lebih sering melaksanakan kegiatan praktikum, tentunya kegiatan evaluasi pun lebih sering dilaksanakan untuk menilai hasil pembelajaran peserta didik pada kegiatan praktikum (Basuki dan Hariyanto, 2014).

\footnotetext{
${ }^{1}$ Mahasiswa Departemen Pendidikan Teknik Mesin FPTK UPI

2 Dosen Departemen Pendidikan Teknik Mesin FPTK UPI

${ }^{3}$ Dosen Departemen Pendidikan Teknik Mesin FPTK UPI
} 
Hasil wawancara menunjukkan bahwa peserta didik belum terlibat didalam kegiatan evaluasi. Penyebabnya adalah terbatasnya waktu untuk kegiatan evaluasi sehingga peserta didik tidak dapat dilibatkan dalam kegiatan tersebut. Tidak terlibatnya peserta didik dalam kegiatan evaluasi pembelajaran berdampak pada peserta didik tidak bisa mengevaluasi dirinya sendiri dan temannya (Brown and Haris, 2014). Selain itu peserta didik tidak mengetahui kriteria penilaian produk praktikum yang benar atau sesuai. Keterlibatan peserta didik dalam penilaian hasil kegiatan praktikum peserta didik dapat memberikan dampak positif bagi peserta didik, seperti dapat berfikir kritis, jujur, objektif serta dapat memberikan umpan balik bagi peserta didik untuk memperbaiki hasil belajarnya (El-Koumy, 2010).

Penilaian hasil produk praktikum peserta didik yang hanya dilakukan oleh pendidik memiliki kekurangan. Kekurangan tersebut diantaranya pendidik kesulitan untuk memperhatikan secara teliti terhadap hasil produk praktikum pada masing-masing peserta didiknya (Wijayanti dan Mundilarto, 2015). Hal ini menyebabkan luputnya perhatian pendidik terhadap penilaian hasil produk praktikum pada sebagian peserta didik. Self assessment dan peer assessment pada kegiatan pembelajaran belum banyak dilakukan, karena pendidik lebih banyak menggunakan penilaian yang bersifat tes, kuis atau tanya jawab (Muslich, 2014).

Peranan pendidik sangat penting dalam melaksanakan kegiatan belajar mengajar. Oleh karena itu, perlu dicari alternatif bentuk penilaian lain yang dapat diterapkan. Salah satu alternatif bentuk penilaian yang dapat digunakan yaitu menerapkan penilian diri dan teman sebaya (self and peer assessment) khususnya pada kegiatan praktikum (Hamzah dan Koni, 2014). Self assessment secara terpisah memiliki kelebihan adanya ketertiban peserta didik dalam proses pembelajaran sehingga peserta didik dapat mengetahui kekurangan dalam belajar (Ardita, 2013). Hal ini dapat dijadikan umpan balik bagi peserta didik untuk memperbaiki hasil belajar selanjutnya. Self assessment sering dikombinasikan dengan peer assessment karena memiliki keuntungan. Peer assessment dapat membantu self assessment. Dengan menilai perkerjaan rekannya, peserta didik mendapatkan pengetahuan untuk membantu kemampuannya (Sholeh, 2014).

\section{METODE PENELITIAN}

Metode yang digunakan pada penelitian ini adalah metode deskriptif dengan pendekatan kuantitatif. Penelitian ini menggambarkan kondisi atau fenomena peer assessment dan self assessment dalam kegiatan pembelajaran. Metode penelitian deskrptif 
dengan pendakatan kuantitatif dipilih untuk mendeskripsikan atau menggambarkan mengenai penilaian kerja peserta didik dengan menggunakan self and peer assessment untuk hasil produk pada mata kuliah body otomotif.

Populasi penelitian yaitu mahasiswa konsentrasi otomotif DPTM FPTK UPI S1 angkatan 2013 yang sudah lulus mata kuliah body otomotifyang berjumlah 53 mahasiswa. Penentuan sampel menggunakan purposive sample yaitu teknik pengambilan sampel sumber data dengan pertimbangan tertentu. Jumlah sample dalam penelitian ini berjumlah 20 orang. Instrumen yang digunakan adalah lembar penilaian produk.

\section{HASIL PENELITIAN}

Penilaian diri (self assessment) untuk hasil produk pada mata kuliah body otomotif berupa miniatur mobil yang dinilai oleh dirinya sendiri adalah baik dengan keseluruhan hasil nilai didapat 76,25 pada katagori terampil. Peer assessment atau penilaian teman sebaya untuk hasil produk mata kuliah body otomotif berupa miniatur mobil adalah baik dengan keseluruhan hasil nilai didapat 75 pada katagori terampil. Assessmen dosen untuk hasil produk pada mata kuliah body otomotif berupa miniatur mobil adalah baik dengan keseluruhan hasil nilai didapat 84 pada katagori terampil.

\section{PEMBAHASAN}

Hasil perhitungan dan analisis data yang telah dilakukan dalam penelitian ini menunjukan bahwa self assessment untuk hasil produk miniatur mobil didapat nilai 76,25 pada kategori terampil. Hasil self assessment itu dibandingkan dengan assessment dosen. Pada assessment dosen berdasarkan hasil perhitungan dan analisis data yang telah dilakukan dalam penelitian ini menunjukan bahwa assessment dosen nilainya adalah 84 pada kategori terampil.

Peer assessment untuk hasil produk miniatur mobil didapat nilai 75 pada kategori terampil. Asessment dosen untuk hasil produk miniatur mobil didapat nilai 84 pada kategori terampil. Kemampuan peserta didik dalam melakukan peer assessment dapat dilihat dengan membandingkan penilaian peserta didik dengan assessment dosen. Secara umum perbandingan hasil penilaian produk mata kuliah body otomotif berupa miniatur mobil yang dilakukan oleh peer assessment dan assessment dosen memiliki kesamaan yang termasuk dalam katagori terampil (Rochmiyati, 2013). peer assessment untuk evaluasi penilaian ini mendapatkan nilai rata-rata peer assessment dan assessment dosen masuk dalam katagori yang sama yaitu dalam katagori terampil. 
Assessment dosen untuk hasil produk miniatur mobil didapat nilai 84 pada kategori terampil secara keseluruhan. Katagori penilaian yang didapat adalah penilaian bentuk produk mobil dengan hasil penilaian adalah 84 , katagori penilaian cat dan warna produk mobil dengan hasil penilaian adalah 84 , katagori kelengkapan produk mobil adalah dengan nilai 83. Hasil assessment dosen itu didapat dari salah satu dosen mata kuliah body otomotif, pada assessment mempunyai aspek-aspek yang dinilai salah satunya adalah aspek penilai hasil produk mata kuliah body otomotif. Aspek yang diperhitungkan dan dianalisis adalah aspek penilaian hasil produk mata kuliah body otomotif untuk menjadi pembanding untuk penilaian diri atau self assessment dan penilaian teman sebaya atau peer assessment. Perbandingan itu dilakukan untuk mengetahui apakah penilaian diri atau self assessment dan penilaian teman sebaya atau peer assessment sesuai dengan hasil penilaian dosen atau assessment dosen.

Secara keseluruhan hasil perhitungan dan analisis data yang telah dilakukan dalam penelitian ini yang bertujuan untuk mengetahui hasil evaluasi self dan peer assessment dibandingkan dengan assessment dosen untuk hasil produk mata kuliah body otomotif. Hasil penilaian menunjukan bahwa self and peer assessment dibandingkan dengan assessment dosen (Onuka, 2007). Hasil produk miniatur mobil didapat nilai 84 pada kategori terampil untuk assessment dosen dan nilai 76 untuk hasil penilaian self dan peer assessment pada katagori terampil. Hasil perbandingan antara self dan peer assessment dengan assessment dosen masuk dalam katagori yang sama yaitu katagori terampil.

Keriteria pada setiap penilaian adalah keriteria bentuk produk mobil dengan nilai yang didapat adalah 74 pada katagori terampil untuk self dan peer assessment, sedangkan untuk assessment dosen didapatkan nilai 84 pada katagori terampil. Keriteria cat dan warna produk mobil hasilnya adalah dengan nilai 73 pada katagori cukup terampil untuk self dan peer assessment. Assessment dosen adalah nilainya 84 pada katagori terampil. Keriteria yang terakir adalah kelengkapan produk mobil dengan hasil nilai adalah 80 pada katagori terampil untuk self dan peer assessment, nilai 83 pada katagori terampil untuk assessment dosen.

Implikasi terhadap proses evaluasi berpengaruh dapat menghasilkan peserta didik yang lebih aktif, berkembang dalam kegiatan pembelajaran, dan menjadi individu yang mampu mengintrospeksi diri dan teman sebaya (Harrison, et. al., 2010). Hasil penilaian diri dan penilaian teman sebaya (self assessment and peer assessment) untuk hasil produk pada mata kuliah body otomotif adalah terbukti sama dengan assessment dosen dengan nilai yang masuk dalam katagori yang sama. Penelitian ini bisa dijadikan oleh pendidik sebagai salah satu inovasi dan alternatif dalam proses evaluasi. 


\section{KESIMPULAN}

Hasil penelitian yang dilakukan oleh peneliti menunjukkan bahwa nilai rata-rata self and peer assessment sama dengan assessment dosen yang memberikan pengaruh dampak positif pada evaluasi. Self and peer assessment merupakan salah satu alternatif penilaian yang bisa digunakan.

\section{REFERENSI}

Ardita. dkk. (2013). Upaya Peningkatan Prestasi Belajar Mata Pelajaran Akutansi dengan Pendekatan Kooperatif Tipe Peer Assessment. Jurnal Pendidikan UNS, 1 (3), hlm 113.

Basuki, I. dan Hariyanto. (2014). Asesmen Pembelajaran. Bandung. PT. Remaja Rosdakarya.

Brown, G. T. L and Haris, L. R. (2014). The Future of Self-Assessment in Classroom practice: Referaming Self-Assessment as a Core Competency. Journal Frontline Learning Research, (3), hlm. 22-30.

El-Koumy, A. K. (2010). Student Self-assessment in Higher Education: Alone or Plus? Lebanon: Lebanese American University.

Hamzah, B. dan Koni, S. (2014). Assessment Pembelajaran. Jakarta: PT Bumi Aksara.

Harrison, K., O`Hara, J., and McNamara, G. (2010). Re-Thinking Assessment: Self-and peer-Assessment as Drivers of Self-Direction in Learning. Eurasian Journal of Educational Research, (60), hlm. 75-88.

Muslich, M. (2014). Pengembangan Model Assessment Afektif Berbasis Self-Assessment dan Peer Assessment di SMA Negeri 1 Kebomas. Jurnal Kebijakan dan Pengembangan Pendidikan, 2 (2), hlm. 143-148.

Onuka, A. O. U. (2007). Teacher-Initieated Student-Peer Asessment: A Means of Improving Learning-Assessment in Large Classes. International Journal of African \& African American Studies, 6 (1), hlm 18-24.

Putra, S. R. (2012). Desain Evaluasi Belajar Berbasis Kinerja. Jogjakarta: DIVA Press.

Rochmiyati. (2013). Model Peer Assessment Pada Pembelajaran Kolaboratif Elaborasi IPS Terpadu Di Sekolah Menengah Pertama. Jurnal Penelitian dan Evaluasi Pendidikan, 1 (2), hlm. 333-346.

Sholeh, M. et.al. (2014). Eksperiment Model Pembelajaran Kooperatif Tipe Numbered Head Together (NHT) dengan Assessment for Learning (AFL) Melalui Penilaian Teman Sejawat pada Materi Persamaan Garis Ditinjau dari Kreativitas Belajar Matematika Siswa MTsN Di Kabupaten Sragen. Jurnal Elektronik Pembelajaran Matematika, 2(7), hlm 667-679. 
Wijayanti, E. dan Mundilarto. (2015). Pengembangan Instrumen Asesmen Diri dan Teman Sejawat Kompetensi Bidang Studi pada Mahasiswa. Jurnal penelitian dan Evaluasi Pendidikan, 19 (2), hlm. 129-144.

Zulharman. (2007). Self dan Peer Assessment sebagai Penilaian Formatif dan Sumatif. Yogyakarta: Fakultas Kedokteran, Universitas Gajah Mada. 